Journal of Agricultural Sciences
(Tarim Bilimleri Dergisi)

\title{
Effects of Foliar Applications on Nutrient Concentrations of Kernel, Pomological Properties and Yield of 'Chandler' Walnut Variety at Different Altitudes
}

\author{
Nihal ACARSOY BILGIN ${ }^{*}$ (DD

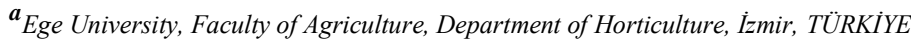 \\ ARTICLE INFO \\ Research Article \\ Corresponding Author: Nihal ACARSOY BILGIN, E-mail: nihal.acarsoy@ege.edu.tr \\ Received: 21 April 2020 / Revised: 07 November 2021 / Accepted: 07 November 2021 / Online: 15 October 2022 \\ Cite this article \\ BíLGiN A N (2022). Effects of Foliar Applications on Nutrient Concentrations of Kernel, Pomological Properties and Yield of 'Chandler' Walnut Variety at Different Altitudes. \\ Journal of Agricultural Sciences (Tarim Bilimleri Dergisi), 28(4):603-612. DOI: 10.15832/ankutbd.925268
}

\section{ABSTRACT}

In Turkey, the orchards are being established with the 'Chandler' walnut variety in different ecologies, nowadays. Plant nutrition applications are important for optimum yield and quality in terms of growing. In this study conducted at two different altitudes (51 and $740 \mathrm{~m})$ in the orchard, foliar application as urea $(5 \mathrm{gr} / \mathrm{L})$, potassium nitrate $(10 \mathrm{gr} / \mathrm{L})$, borax $(1 \mathrm{gr} / \mathrm{L})$, manganese sulfate $(2 \mathrm{gr} / \mathrm{L})$ and zinc sulfate $(1.5 \mathrm{gr} / \mathrm{L})$ were sprayed for two years. Following the application, macro and micro nutrient content of kernel and fruit properties were determined. According to this, it was observed that foliar application of boron (B) in terms of nut weight and foliar application of potassium $(\mathrm{K})$ in terms of kernel ratio ranked the first row. The shrinkage ratio, an important quality criterion for walnuts, was found to be low in the high altitude Demirci location (17.43\%). However, in the low altitude Saruhanlı location, the shrinkage ratio was reduced with foliar K application. In addition, while all foliar applications had a positive effect on yield, the highest value was measured in Saruhanl location $\left(3.31 \mathrm{~kg} \mathrm{tree}^{-1}\right)$. The macro and micro nutrient content of kernel evaluated, there was an increase in nutrients in the second year, except for $\mathrm{K}$, calcium $(\mathrm{Ca})$ and magnesium $(\mathrm{Mg})$. Phosphorus $(0.29$ and $0.27 \%)$, iron (30.64 and $6.24 \mathrm{ppm})$, copper (7.64 and $11.35 \mathrm{ppm})$, zinc (32.42 and $27.03 \mathrm{ppm}$ ) and manganese (25.77 and $30.05 \mathrm{ppm})$ contents of the grain were found to be significant for Demirci and Saruhanlı locations, respectively. Values in Demirci location were higher than Saruhanli location. Additionally, it was also revealed in interaction.

Keywords: Juglans regia, Macro and micro nutrients, Fruit quality, Location x year x application interaction

\section{Introduction}

Walnut is one of the most important hard nut fruit species in the world. Yield and quality characteristics vary depending on the variety and ecological conditions at different altitudes. As it is known, high yield is the most important among production targets in terms of growing. Macro and micro nutrients have an important effect on this matter (Khayyat et al. 2007). For a long time, intensive use of soil fertilizers has caused significant soil and water-related environmental problems (Rios et al. 2020). Management of nutrients is one of the basic principles of sustainable agriculture. In this context, foliar fertilization is considered an environmentally friendly practice (Norozi et al. 2019). In plants, especially in periods when their uptake is limited and their requirements are high, nutrients must be taken from the leaves. Foliar sprays are the most effective and very rapid treatment (Fernandez et al. 2013; Ghani et al. 2021). The use of foliar fertilizer is common due to these properties (Rios et al. 2019). Nitrogen is the basic plant nutrient. When sprayed in urea form, it improves diffusion conditions by increasing the permeability of the cutin layer. In this way, it is reported to be high uptake (Kacar \& Katkat 2006). Foliar N fertilizer application contributes to the rapid development of shoots in the spring period ( $\mathrm{Xu}$ et al. 2021). At the same time, $\mathrm{N}$ is an important element for the synthesis of organic compounds (Carranca et al. 2018).

Another nutrient necessary for flowering and fruit formation is potassium (K). For this species with high oil content, the trees must be fertilized with K. Nut fruit species require a high amount of potassium during the fruit development period. In this case, foliar spraying is reported as an effective and rapid application in terms of potassium supply (Norozi et al. 2019; Marchand 2020).

In addition, micro-elements are effective in plant nutrition programs (Dejampour \& Zeinalabedini 2006; Y1ld1z et al. 2007). In salty, calcareous and high $\mathrm{pH}$ soils, micronutrient deficiencies are eliminated by foliar application. This method is preferred because it is fast, cheap and target-oriented (Rios et al. 2019; Xie et al. 2020). 
Some fruit species need high boron (B) element especially during blooming. For nut species, this element is often recommended in the fertilization program (Ellis 2016). High of $\mathrm{pH}$ and calcium carbonate in the experimental area soils cause low efficiency of soil-applied B fertilizers (Khoshgoftarmanesh 2012). Therefore, it can be easily transported to different organs of the tree through phloem by foliar application. Foliar B applications performed during this development period lead to fruit set and consequently increase in yield (Brown 2001; Khayyat et al. 2007). With application B, the yield of cashew nut per tree increased significantly compared to the control trees (Gavit et al. 2020). Similarly, in hazelnut, the best findings on yield and some fruit quality traits were obtained with B treatments (Horuz et al. 2021).

Zinc (Zn), which is another essential element in plant physiology, has an effect on yield and quality. Soil-applied Zn is not supplying enough $\mathrm{Zn}$ to the trees. This is due to the deep penetration of the roots and the difficult progression of $\mathrm{Zn}$ in the soil. Foliar $\mathrm{Zn}$ application is a common practice to compensate for $\mathrm{Zn}$ deficiency (Smith et al. 2021). In pistachio, it is mentioned that the application of leaf Zn spray during bud swelling and green tip period has a positive effect on fruit yield and quality, especially splitting. This application is foreseen as a solution in calcareous soils (Norozi et al. 2019).

Manganese (Mn) should be included in walnut growing programs. In cold and rainy conditions, plant root activity decreases and Mn uptake decreases. While $\mathrm{Mn}$ is very high in acid soils, Mn uptake is low in high pH soils. In walnuts, a significant decrease in leaf Mn concentration was observed during fruit development (Kim \& Wetzstein 2005). For these reasons, similar to other elements, foliar spray treatments are more effective (Hounnou et al. 2019).

Walnut is considered as a good source of macro and micro nutrients composition. In particular, walnuts are rich in $\mathrm{K}$, which consume very important for human health. On the other hand, $\mathrm{P}, \mathrm{Ca}, \mathrm{Mg}$ and $\mathrm{Na}$ content is also high (Y1ldı \& Sümbül, 2019a). Copper, Fe, and Zn contained in walnuts are necessary micronutrients for important for human metabolism (Scherz \& Kirchhoff 2006). Therefore, it is present in all diet programs, including the vegetarian and vegan diet (Abdallah et al. 2015). After all, walnuts are an important food in the supply of essential elements to the human body (Simsek 2016). It was stated that nutrient content may be varied due to effects such as variety, year, ecology, maturity level and the methods of cultivation (Juranovic Cindric et al. 2018; Kabiri et al. 2019). Further, fruit quality features were improved with plant nutrition applications. In previous studies, the nutrient content of walnut kernel was revealed in different locations (Gülsoy et al. 2016; Batun et al. 2017; Kabiri et al. 2019; Ozyigit et al. 2019). In walnuts, these macro-micronutrients are extremely important in terms of fruit development, yield and quality. Additionally, it has been concluded that foliar application of $\mathrm{K}$ and $\mathrm{Zn}$ fertilizers is necessary to obtain better fruit yield and quality in pistachio (Norozi et al. 2019). In the light of the above explanations, in this study, it was aimed to determine the effects of macro and micro foliar application on nutrient content of kernel, some fruit properties and yield of 'Chandler' walnut variety in different ecological conditions with two distinct altitudes (51 and $740 \mathrm{~m})$.

\section{Material and Methods}

Field studies were conducted in a commercial orchard located in Saruhanl $\left(38^{\circ} 47^{\prime} 31^{\prime \prime}\right.$ N $27^{\circ} 30^{\prime} 22^{\prime \prime}$ E, altitude 51 m) and Demirci (39 $02^{\prime} 39^{\prime \prime} \mathrm{N} 28^{\circ} 35^{\prime} 56^{\prime \prime} \mathrm{E}$, altitude $740 \mathrm{~m}$ ), Manisa province, Turkey. Drip irrigation is applied to the trees in both orchards. There is a homogeneous situation in terms of the amount of water. The maximum and minimum temperature values for the years in which the trial was conducted are presented in Table 1. Soil analysis results of the experimental orchard are given in Table 2. It was determined that the soil was loamy, slightly alkaline, moderately calcareous, poor in organic matter and saltfree. 'Chandler' walnut variety (5-years-old) was used as plant material during 2017 and 2018 years. This variety has moderately strong growth habit and winter chilling requirement is defined 700 hours. In addition, its foliation and blooming are the late period. Nuts ripening in the mid-season are large, smooth, oval shaped and fragile shell (Özçağıran et al. 2014).

Table 1- Monthly temperature values $\left({ }^{\circ} \mathrm{C}\right)$

\begin{tabular}{ccccccccc}
\hline & \multicolumn{4}{c}{ Saruhanl } & \multicolumn{4}{c}{ Demirci } \\
\cline { 2 - 9 } Month & \multicolumn{2}{c}{ 2017 } & \multicolumn{2}{c}{ 2018 } & \multicolumn{2}{c}{ 2017 } & \multicolumn{2}{c}{ 2018 } \\
\cline { 2 - 9 } & Max & Min & Max & Min & Max & Min & Max & Min \\
\hline $\mathbf{1}$ & 9.0 & -0.3 & 12.1 & 1.6 & 4.4 & -1.8 & 9.3 & 2.9 \\
$\mathbf{2}$ & 14.7 & 2.9 & 15.8 & 5.6 & 9.6 & 2.4 & 11.6 & 5.2 \\
$\mathbf{3}$ & 19.6 & 5.6 & 20.3 & 7.9 & 14.3 & 5.4 & 15.0 & 6.9 \\
$\mathbf{4}$ & 23.9 & 6.7 & 28.4 & 8.7 & 17.8 & 8.1 & 23.1 & 12.4 \\
$\mathbf{5}$ & 28.7 & 11.7 & 30.8 & 14.8 & 21.7 & 11.9 & 24.7 & 14.3 \\
$\mathbf{6}$ & 34.1 & 16.6 & 33.3 & 16.5 & 27.0 & 16.2 & 27.5 & 16.7 \\
$\mathbf{7}$ & 36.6 & 18.6 & 35.6 & 19.1 & 31.7 & 19.9 & 30.3 & 19.2 \\
$\mathbf{8}$ & 35.0 & 19.4 & 36.6 & 20.6 & 30.2 & 19.0 & 31.4 & 20.1 \\
$\mathbf{9}$ & 33.6 & 13.3 & 32.1 & 15.9 & 29.1 & 16.9 & 27.2 & 16.8 \\
$\mathbf{1 0}$ & 25.2 & 8.0 & 25.9 & 9.8 & 19.5 & 10.1 & 22.1 & 12.1 \\
$\mathbf{1 1}$ & 18.8 & 3.2 & 19.2 & 6.7 & 13.9 & 6.1 & 16.1 & 8.6 \\
$\mathbf{1 2}$ & 15.0 & 5.1 & 11.0 & 2.2 & 10.5 & 4.7 & 8.3 & 2.0 \\
\hline
\end{tabular}


Table 2- Soil analysis results at two depths $(0-30 \mathrm{~cm}$ and $30-60 \mathrm{~cm})$

\begin{tabular}{|c|c|c|c|c|c|c|c|c|}
\hline \multirow{2}{*}{ Soil Parameters } & \multicolumn{4}{|c|}{ Demirci } & \multicolumn{4}{|c|}{ Saruhanll } \\
\hline & \multicolumn{2}{|r|}{$0-30 \mathrm{~cm}$} & \multicolumn{2}{|r|}{$30-60 \mathrm{~cm}$} & \multicolumn{2}{|c|}{$0-30 \mathrm{~cm}$} & \multicolumn{2}{|r|}{$30-60 \mathrm{~cm}$} \\
\hline $\mathrm{pH}$ & 7.77 & Alkaline & 7.71 & Alkaline & 7.74 & Alkaline & 7.85 & Alkaline \\
\hline $\mathrm{EC}(\%)$ & 0.038 & Salt-free & 0.048 & Salt-free & 0.046 & Salt-free & 0.047 & Salt-free \\
\hline $\mathrm{CaCO}_{3}(\%)$ & 27.13 & High & 31.92 & High & 9.98 & Medium & 10.77 & Medium \\
\hline Sand $(\%)$ & 42.24 & & 46.24 & & 44.24 & & 44.24 & \\
\hline Clay (\%) & 28.00 & & 24.00 & & 30.00 & & 30.00 & \\
\hline Silt (\%) & 29.76 & & 29.76 & & 25.76 & & 25.76 & \\
\hline Texture & & Clay loam soil & & Clay loam sand & & Loamy soil & & Loamy soil \\
\hline Organic Matter (\%) & 3.39 & Sufficient & 2.90 & Sufficient & 0.68 & Insufficient & 0.14 & Insufficient \\
\hline Total N (\%) & 0.123 & Sufficient & 0.106 & Sufficient & 0.062 & Insufficient & 0.056 & Insufficient \\
\hline Available P (ppm) & 0.20 & Insufficient & 0.40 & Insufficient & 0.80 & Insufficient & 0.2 & Insufficient \\
\hline Available K (ppm) & 397.70 & Sufficient & 329.8 & Sufficient & 358.9 & Sufficient & 310.4 & Sufficient \\
\hline Available Ca (ppm) & 5529 & High & 5238 & High & 5238 & High & 5044 & High \\
\hline Available Mg (ppm) & 351.60 & High & 401.70 & High & 632 & High & 649 & High \\
\hline Available Na (ppm) & 19.80 & Normal & 96.10 & Normal & 150.4 & Normal & 37.6 & Normal \\
\hline Available Fe (ppm) & 3.80 & Normal & 3.34 & Normal & 6.31 & Sufficient & 1.14 & Insufficient \\
\hline Available Zn (ppm) & 0.49 & Sufficient & 0.77 & Insufficient & 0.42 & Insufficient & 0.54 & Insufficient \\
\hline Available $\mathrm{Cu}$ (ppm) & 1.53 & Sufficient & 1.33 & Sufficient & 1.34 & Sufficient & 0.82 & Sufficient \\
\hline Available Mn (ppm) & 8.12 & Sufficient & 6.58 & Sufficient & 5.8 & Sufficient & 3.46 & Sufficient \\
\hline Soluble B (ppm) & 0.51 & Insufficient & 0.54 & Insufficient & 0.32 & Insufficient & 0.4 & Insufficient \\
\hline
\end{tabular}

Foliar applications were sprayed as $\mathrm{N}$ (urea, $5 \mathrm{gr} / \mathrm{L}$ ), $\mathrm{K}$ (potassium nitrate, $10 \mathrm{gr} / \mathrm{L}$ ), B (borax, $1 \mathrm{gr} / \mathrm{L}$ ), Mn (manganese sulfate, $2 \mathrm{gr} / \mathrm{L}$ ), $\mathrm{Zn}$ (zinc sulfate, $1.5 \mathrm{gr} / \mathrm{L}$ ) and control (untreated trees). As it is known, macro and micro nutrients are effective on fruit growth, yield and quality parameters of plants. In foliar fertilizers, the application dose should not exceed $0.1-0.2 \%$ in micro elements and 1-2\% in macro elements on the basis of the active substance (except low biurea urea). Application doses and times vary according to the development period of the plant and the thickness of the leaf cuticle layer (Kacar 1982; Epstein \& Bloom 2005; Çolakoğlu \& Çiçekli 2016; Fernandez et al. 2013). Foliar application should be applied 2-3 times at 15-20 days intervals after flowering, which is the critical period for plants (Çolakoğlu \& Çiçekli 2016).

It was carried out twice for each nutrient element. For B, the first application was made before the male flowers bloom, and the second application two - three weeks later. For N, K, Zn, Mn, the first application was made, after the male flowers bloomed, the second application was made two - three weeks later (Norozi et al. 2019).

The harvested fruits were separated from green peels and dried in the shade. Average nut weight was determined on precision electronic scale $(0.01 \mathrm{~g})$ then the kernel ratio $(\%)$ was calculated. Fruit color was measured by a CR400 model Minolta Colorimeter in CIE L* $\mathrm{a}^{*} \mathrm{~b}^{*}$. In fruit which is accepted as 4 parts the shrinkage ratio of each part was determined as \% (Şen, 1980; Beyhan, 1993; Aşkın \& Gün, 1995). For yield, the total amount of nut was recorded in each tree at harvest time (kg). The kernel samples were dried at $65^{\circ} \mathrm{C}$ in the oven until constant weight is achieved (24-48 hours), for nutrient analysis. These samples were crushed and ground (Analytical Mill, IKA A 11 BASIC). The Kjeldahl method for N (Gerhardt Germany); the colorimetric method for P (AnalytikJena AG Germany); the flame fotometric method for Ca and K (Eppendorf Geratebaue \& Netheler Hinz Gmbh Germany); atomic absorption spectrophotometer for $\mathrm{Mg}, \mathrm{Fe}, \mathrm{Cu}, \mathrm{Zn}$ and $\mathrm{Mn}$ (Varian Spektr AA 220); spectrophotometic with Azomethhin-H method for B analyses were used (Varian Spektr AA 220) (Wolf 1971; Kacar \& İnal 2008).

The experiment was carried out according to the design of the random blocks, with 3 replications and 3 trees per replication. 30 fruits were evaluated each year. The data were subjected to analysis of variance using SPSS 20 statistical package program. Significant differences between averages were defined by Duncan test at the $\mathrm{P}<0.05$ significant level.

\section{Results}

\subsection{Fruit properties and yield}

In the evaluation made according to applications, years and locations, there was a statistical difference in the nut properties, in general except for the kernel color $\mathrm{L}^{*}$ and $\mathrm{a}^{*}$ value (Table 3). According to this, the highest nut weight was measured with $\mathrm{B}$ application at Saruhanlı location in 2017 and at Demirci location in both years (2017 and 2018). In contrast, the lowest value was measured in the untreated trees. Kernel ratio varied according to applications. The highest kernel ratio was obtained from B application with 54.96\% at the Saruhanl location in 2018 and K application with 57.55\% at Demirci location in 2017. For b* value, a statistical difference was found at Saruhanlı in the second year and at Demirci in both years. However, applications varied on the yellow color of the kernel. The effect of applications on the shrinkage ratio of the kernel was statistically significant effective in the first year of the experiment in both locations. Accordingly, the shrinkage ratio of the kernel was found in the range of $22.50 \%-56.66 \%$ in Saruhanl 1 and $8.33 \%-30.00 \%$ in Demirci. The highest yield was achieved with control application at Saruhanlı in 2017, but at Demirci, with Zn application in both years. 
According to the years; nut weight; shrinkage ratio and yield statistical difference was observed (Table 4). Thus, an increase in the features mentioned was detected in 2018. On the other hand, the statistical differences were found between locations in the majority of the properties (except nut weight and kernel ratio). It was calculated that $\mathrm{L}^{*}$ value (54.07), a* value (7.22) and shrinkage ratio $(17.43 \%)$ had better results in Demirci location, while b* value (27.77) and yield $\left(3.31 \mathrm{~kg}^{*} \mathrm{tree}^{-1}\right)$ in Saruhanlı location. On the basis of applications, it was observed that foliar application of B in terms of nut weight (13.70 g) and foliar application of $\mathrm{K}$ in terms of kernel ratio $(52.01 \%)$ ranked the first row. For shrinkage ratio, applications were in the same statistical group, except $\mathrm{N}$ and $\mathrm{Mn}$. All applications, except untreated trees, had an impact on yield. In addition, it was determined that foliar nutrient applications were not effective on kernel color values.

It was found out that year*location interaction for nut weight; location*application for shrinkage ratio; year*application interaction for $\mathrm{b}^{*}$ value and location* year* application interaction for shrinkage ratio were significant. For the year* location interaction, changes in locations based on years were important in terms of nut weight. In terms of average value of nut weight, it varied between $12.60 \mathrm{~g}$ (2017) and $13.60 \mathrm{~g}$ (2018) in Saruhanlı location (Table 3).

To be into account year* application interaction, $b^{*}$ value of kernel was determined to be effective. Accordingly, the highest value was obtained from Mn application (30.05 and 29.38) with an average of 29.72 in 2018. For location* application interaction, it was found important in terms of shrinkage ratio. Regarding this feature, in the evaluation made according to the average of the data for both years in Table 3, the highest value was determined from B application (11.66\% and 9.16\%) with an average of $10.41 \%$ in Demirci location. However, the lowest value was stated from N application $(56.66 \%$ and $36.66 \%)$ with an average of $46.66 \%$ in other location. In terms of the same feature, location* year* application interaction was important. Thus, the shrinkage ratio ranged from 5.83\% (with Mn application in Demirci location in 2018) to 56.66\% (with N application in Saruhanlı location in 2017).

Table 3- Location, year and application values of the nut properties

\begin{tabular}{|c|c|c|c|c|c|c|c|c|c|}
\hline Location & Year & Application & $\begin{array}{c}\text { Nut weight } \\
\text { (g) }\end{array}$ & $\begin{array}{c}\text { Kernel ratio } \\
(\%)\end{array}$ & $L^{*}$ value & $a^{*}$ value & $b^{*}$ value & $\begin{array}{c}\text { Shrinkage } \\
\text { ratio (\%) }\end{array}$ & $\begin{array}{c}\text { Yield } \\
\text { (kg/tree) }\end{array}$ \\
\hline \multirow{10}{*}{ Saruhanlı } & \multirow{5}{*}{2017} & Control & $12.27 \mathrm{~b}$ & 50.17 & 51.34 & 8.75 & 29.87 & $29.16 \mathrm{ab}$ & $1.79 \mathrm{~b}$ \\
\hline & & $\mathrm{K}$ & $12.58 \mathrm{ab}$ & 50.75 & 52.43 & 8.53 & 29.23 & $22.50 \mathrm{a}$ & $1.99 \mathrm{ab}$ \\
\hline & & $\mathrm{N}$ & $12.29 \mathrm{~b}$ & 51.08 & 51.40 & 7.86 & 29.74 & $56.66 \mathrm{c}$ & $2.11 \mathrm{ab}$ \\
\hline & & $\mathrm{Mn}$ & $12.59 \mathrm{ab}$ & 52.00 & 51.09 & 8.34 & 28.78 & $34.16 \mathrm{ab}$ & $3.21 \mathrm{ab}$ \\
\hline & & $\mathrm{Zn}$ & $12.56 \mathrm{ab}$ & 49.22 & 50.25 & 8.05 & 29.48 & $45.00 \mathrm{bc}$ & $2.40 \mathrm{ab}$ \\
\hline & \multirow{5}{*}{2018} & $\mathrm{~K}$ & 12.76 & $54.31 \mathrm{ab}$ & 52.75 & 8.39 & $30.46 \mathrm{a}$ & 21.66 & 4.50 \\
\hline & & B & 13.82 & $54.96 \mathrm{a}$ & 51.28 & 8.42 & $29.22 b$ & 22.50 & 4.34 \\
\hline & & $\mathrm{N}$ & 13.63 & $51.67 \mathrm{abc}$ & 51.90 & 7.95 & $29.92 \mathrm{ab}$ & 36.66 & 3.89 \\
\hline & & $\mathrm{Mn}$ & 13.81 & $48.51 \mathrm{bc}$ & 52.26 & 7.90 & $30.05 \mathrm{ab}$ & 38.33 & 4.01 \\
\hline & & $\mathrm{Zn}$ & 13.69 & $47.95 \mathrm{c}$ & 47.90 & 9.56 & $30.44 \mathrm{a}$ & 31.66 & 4.44 \\
\hline \multirow{11}{*}{ Demirci } & \multirow{6}{*}{2017} & Control & $11.84 \mathrm{~d}$ & $50.59 \mathrm{ab}$ & 52.88 & 6.95 & $28.42 b$ & $35.00 \mathrm{bc}$ & $1.11 \mathrm{~b}$ \\
\hline & & $\mathrm{K}$ & $11.84 \mathrm{~d}$ & $57.55 \mathrm{a}$ & 55.19 & 7.79 & $28.99 \mathrm{ab}$ & $30.00 \mathrm{~b}$ & $1.08 \mathrm{~b}$ \\
\hline & & $\mathrm{N}$ & $12.09 \mathrm{~cd}$ & $44.99 \mathrm{~b}$ & 52.41 & 7.05 & $28.75 \mathrm{ab}$ & $16.66 \mathrm{a}$ & $1.24 \mathrm{~b}$ \\
\hline & & $\mathrm{Mn}$ & $13.05 \mathrm{bc}$ & $49.07 \mathrm{~b}$ & 51.26 & 6.77 & $28.44 \mathrm{~b}$ & $41.66 \mathrm{c}$ & $1.24 \mathrm{~b}$ \\
\hline & & $\mathrm{Zn}$ & $13.14 \mathrm{~b}$ & $48.19 \mathrm{~b}$ & 54.70 & 8.10 & $29.10 \mathrm{a}$ & $8.33 \mathrm{a}$ & $1.79 \mathrm{a}$ \\
\hline & & Control & $11.97 \mathrm{~b}$ & 49.99 & 53.91 & 7.32 & $28.99 \mathrm{ab}$ & 8.33 & $0.77 \mathrm{~b}$ \\
\hline & \multirow{5}{*}{2018} & $\mathrm{~K}$ & $12.18 \mathrm{ab}$ & 45.45 & 55.76 & 7.17 & $28.50 \mathrm{~b}$ & 12.50 & $1.99 \mathrm{ab}$ \\
\hline & & B & $13.53 \mathrm{a}$ & 47.45 & 54.57 & 6.93 & $27.50 \mathrm{c}$ & 9.16 & $1.30 \mathrm{ab}$ \\
\hline & & $\mathrm{N}$ & $12.21 \mathrm{ab}$ & 47.20 & 54.67 & 7.17 & $28.64 \mathrm{ab}$ & 16.66 & $1.92 \mathrm{ab}$ \\
\hline & & $\mathrm{Mn}$ & $12.85 \mathrm{ab}$ & 48.30 & 55.05 & 7.20 & $29.38 \mathrm{a}$ & 5.83 & $1.91 \mathrm{ab}$ \\
\hline & & $\mathrm{Zn}$ & $13.26 \mathrm{ab}$ & 45.57 & 54.63 & 7.51 & $28.74 \mathrm{ab}$ & 13.33 & $3.05 \mathrm{a}$ \\
\hline
\end{tabular}

The differences in the means were determined by the Duncan test according to $\mathrm{P} \leq 0.05$ 
Table 4- Average values of the properties

\begin{tabular}{|c|c|c|c|c|c|c|c|c|}
\hline & & \\
\hline & & $\begin{array}{c}\text { Nut } \\
\text { weight }(g)\end{array}$ & $\begin{array}{c}\text { Kernel } \\
\text { ratio (\%) }\end{array}$ & L*value & $a^{*}$ value & $b^{*}$ value & $\begin{array}{c}\text { Shrinkage } \\
\text { ratio }(\%)\end{array}$ & $\begin{array}{c}\text { Yield } \\
(\mathrm{kg} / \text { tree })\end{array}$ \\
\hline \multirow{2}{*}{ Year } & 2017 & $12.64 \mathrm{~b}$ & 50.49 & 52.28 & 7.82 & 29.15 & $30.97 \mathrm{~b}$ & $1.94 \mathrm{~b}$ \\
\hline & 2018 & $13.13 \mathrm{a}$ & 49.15 & 52.86 & 7.83 & 29.33 & $21.25 \mathrm{a}$ & $2.94 \mathrm{a}$ \\
\hline \multirow{2}{*}{ Location } & Demirci & 12.68 & 48.80 & $54.07 \mathrm{a}$ & $7.22 \mathrm{a}$ & $28.71 \mathrm{~b}$ & $17.43 \mathrm{a}$ & $1.57 \mathrm{~b}$ \\
\hline & Saruhanlı & 13.10 & 50.84 & $51.07 \mathrm{~b}$ & $8.43 \mathrm{~b}$ & $29.77 \mathrm{a}$ & $34.79 \mathrm{~b}$ & $3.31 \mathrm{a}$ \\
\hline \multirow{6}{*}{ Application } & Control & $12.49 \mathrm{~d}$ & $49.80 \mathrm{abc}$ & 51.94 & 7.89 & 29.35 & $27.70 \mathrm{a}$ & $1.71 \mathrm{~b}$ \\
\hline & $\mathrm{K}$ & $12.34 \mathrm{~d}$ & $52.01 \mathrm{a}$ & 54.03 & 7.97 & 29.30 & $21.66 \mathrm{ab}$ & $2.39 \mathrm{a}$ \\
\hline & B & $13.70 \mathrm{a}$ & $51.19 \mathrm{ab}$ & 52.58 & 7.74 & 28.94 & $21.04 \mathrm{ab}$ & $2.73 \mathrm{a}$ \\
\hline & $\mathrm{N}$ & $12.55 \mathrm{~cd}$ & $48.74 \mathrm{bc}$ & 52.59 & 7.51 & 29.26 & $31.66 \mathrm{~b}$ & $2.29 \mathrm{ab}$ \\
\hline & $\mathrm{Mn}$ & $13.07 \mathrm{bc}$ & $49.47 \mathrm{abc}$ & 52.42 & 7.55 & 29.16 & $30.00 \mathrm{~b}$ & $2.59 \mathrm{a}$ \\
\hline & $\mathrm{Zn}$ & $13.16 \mathrm{~b}$ & $47.73 \mathrm{c}$ & 51.87 & 8.30 & 29.44 & $24.58 \mathrm{ab}$ & $2.92 \mathrm{a}$ \\
\hline \multicolumn{2}{|c|}{ Year*Location } & $* *$ & $\mathrm{~ns}$ & $\mathrm{~ns}$ & $\mathrm{~ns}$ & ns & $\mathrm{ns}$ & ns \\
\hline \multicolumn{2}{|c|}{ Location* Application } & ns & ns & ns & ns & ns & $* *$ & ns \\
\hline \multicolumn{2}{|c|}{ Year* Application } & ns & ns & ns & ns & $* *$ & ns & ns \\
\hline \multicolumn{2}{|c|}{ Location* Year* Application } & ns & ns & ns & ns & ns & $*$ & ns \\
\hline
\end{tabular}

*: Significant at $\mathrm{P}<0.05$, **: Significant at $\mathrm{P}<0.01$. ns: Non-significance.

\subsection{Nutrient concentrations of kernel}

As a result of foliar applications, macro and micro nutrient contents determined in 'Chandler' variety are given in Table 5. Foliar $\mathrm{N}$ spray was caused this element content of kernel to be much higher than others in both locations and years. In contrast, control application was observed in the last group. Considering the $\mathrm{P}$ contents of kernels, $\mathrm{K}$ and $\mathrm{Mn}(0.33 \%)$ applications for Demirci and $\mathrm{Zn}(0.31 \%)$ application for Saruhanlı took placed the first row in 2018. In the foliar K spray, this macro element was found to have the highest values as a result of kernel analysis in both locations and years. Whereas, the lowest K content was determined in the control application. All foliar applications had positive effect on this content. It was seen that Ca content of kernel is high for Saruhanl location, K application in 2018; for Demirci location, Zn application in 2017 and Mn application in 2018. The effect of the applications on the $\mathrm{Mg}$ content of kernel was statistically significant. According to this, the highest Mg content of kernel was obtained from Mn application with $0.17 \%$ in 2017 and with $0.20 \%$ in 2018.

For both locations and years, micro elements such as Fe, Zn and Mn were statistically significant. Fe content of kernel was located in the first statistical group in $\mathrm{K}, \mathrm{B}$ and $\mathrm{Mn}$ applications in Saruhanli. Otherwise, the highest kernel Fe content was determined with the $\mathrm{N}$ application in Demirci. In the foliar $\mathrm{Zn}$ application in Saruhanli location, this micro element was found to have the highest values, while the lowest $\mathrm{Zn}$ content of kernel was observed in the control group. A similar situation was determined in Mn content of kernel at the same location. Cu content of kernel was important statistically in Saruhanlı in 2018 and Demirci in both years. This content varied based on year and applications. B content, the most effective application was $\mathrm{N}$ foliar spray, in Saruhanl1. B content reached the highest level in the Demirci location in first year with foliar application of $\mathrm{Zn}$ (2.86 ppm) and second year with foliar application of B (4.53 ppm).

There was a statistical difference in macro and micro nutrients evaluated by years, except for $\mathrm{K}$, Ca and Mg (Table 6). Thus, there was an increase in these nutrients in the second year. When the locations are evaluated, it was found to be an increased that $\mathrm{P}$ for macro and $\mathrm{Fe}, \mathrm{Cu}, \mathrm{Zn}$ and $\mathrm{Mn}$ for micro were significant. Nutrition contents of kernel in Demirci location were higher than the other location. Nitrogen application for $\mathrm{N}$ content of kernel (2.96\%), K application for K content of kernel (0.55\%), Mn and $\mathrm{Zn}$ application for Ca content of kernel (0.10\%), B application for Fe content of kernel (29.76), B application for Cu content of kernel (10.55), Zn application for Zn content of kernel (31.86 ppm), Mn application for Mn content of kernel (31.13 ppm) and $\mathrm{N}$ application for $\mathrm{B}$ content of kernel (3.43 ppm) ranked the first row. Untreated trees formed the last group.

It was stated that location* year interaction for N; location* application for N, Zn, Mn and B; year* application interaction for N, Fe Mn and B and location* year* application interaction for N and Mn were significant. For year* location interaction, it was found important in terms of $\mathrm{N}$ amount of kernel. Considering the average value, the $\mathrm{N}$ content of kernel (2.905\%) took the first place at the Demirci location in 2018 (Table 5). In 2017, the N content of kernel was determined as $2.44 \%$ in the same location. Considering the location* application interaction; in the evaluation made according to the average of the data for both years in Table 5, the highest amount of kernel N was obtained from Mn application (2.84 and 3.23\%) with an average of 3.04\% at the Demirci location. The lowest amount of kernel N was occurred from control application (2.06 and $2.21 \%)$ with an average of 2.14 at the same location. In terms of Zn amount of kernel, Mn application (34.43 and 35.31 ppm) with an average of 34.87 ppm in Demirci location was the first, and control application (17.37 and $20.66 \mathrm{ppm}$ ) with an average of $19.02 \mathrm{ppm}$ in Saruhanl1 was found in the last place. The Mn content of kernel was found in the range of 23.45 (with $\mathrm{Zn}$ application at Demirci location) 
- $31.51 \mathrm{ppm}$ (with K application at Saruhanlı location). In terms of B content of kernel, Mn application (2.97 and $4.17 \mathrm{ppm})$ with an average of $3.57 \mathrm{ppm}$ in Saruhanl1 location was the first, and $\mathrm{N}$ application (3.71 and $1.10 \mathrm{ppm}$ ) with an average of $2.41 \mathrm{ppm}$ in the same location was found in the last place. For the year* application interaction; N, Fe, Mn and B content of kernel were determined to be effective. Accordingly, the highest value N, Fe, Mn and B content of kernel were obtained from foliar $\mathrm{N}$ application (3.05 and 3.26\%) with an average of 3.16\%, Fe application (32.28 and $35.583 \mathrm{ppm}$ ) with an average of 33.93 ppm, Mn application (32.97 and $35.46 \mathrm{ppm}$ ) with an average of $34.22 \mathrm{ppm}$, B application (4.40 and 4.53 ppm) with an average of 4.47 ppm in 2018, respectively. For the location* year* application, $\mathrm{N}$ and $\mathrm{Mn}$ contents of kernel were determined to be effective. The $\mathrm{N}$ content was found in the range of 3.26\% (with N application in Demirci location in 2018) - 2.06\% (with control application in Demirci location in 2017). The Mn of kernel was found in the range of $18.64 \mathrm{ppm}$ (with K application in Demirci location in 2017) - 38.55 ppm (with Mn application in Saruhanlı location in 2018).

Table 5- Location, year and application values of the macro and micro nutrient content of kernel

\begin{tabular}{|c|c|c|c|c|c|c|c|c|c|c|c|c|}
\hline Location & Year & Application & $\begin{array}{l}N \\
(\%)\end{array}$ & $\begin{array}{l}P \\
(\%)\end{array}$ & $\begin{array}{l}K \\
(\%)\end{array}$ & $\begin{array}{l}\mathrm{Ca} \\
(\%)\end{array}$ & $\begin{array}{c}M g \\
(\%)\end{array}$ & $\begin{array}{l}F e \\
(p p m)\end{array}$ & $\begin{array}{l}\boldsymbol{C u} \\
(\text { ppm })\end{array}$ & $\begin{array}{l}\mathrm{Zn} \\
(\text { ppm })\end{array}$ & $\begin{array}{l}\text { Mn } \\
(\text { ppm })\end{array}$ & $\begin{array}{l}B \\
(p p m)\end{array}$ \\
\hline \multirow{12}{*}{ Saruhanlı } & \multirow{7}{*}{2017} & Control & $2.30 \mathrm{c}$ & 0.24 & $0.40 \mathrm{c}$ & 0.03 & 0.10 & $18.98 \mathrm{~b}$ & 11.31 & $17.37 \mathrm{c}$ & $23.83 \mathrm{c}$ & $2.34 \mathrm{c}$ \\
\hline & & $\mathrm{K}$ & $2.78 \mathrm{a}$ & 0.26 & $0.54 \mathrm{a}$ & 0.06 & 0.10 & $24.85 \mathrm{a}$ & 11.51 & $26.75 \mathrm{~b}$ & $30.05 \mathrm{ab}$ & $2.47 \mathrm{bc}$ \\
\hline & & B & $2.41 \mathrm{bc}$ & 0.27 & $0.46 \mathrm{bc}$ & 0.10 & 0.16 & $27.62 \mathrm{a}$ & 12.16 & $26.54 \mathrm{~b}$ & $22.47 \mathrm{c}$ & $2.12 \mathrm{c}$ \\
\hline & & $\mathrm{N}$ & $2.78 \mathrm{a}$ & 0.29 & $0.46 \mathrm{bc}$ & 0.06 & 0.16 & $26.00 \mathrm{a}$ & 10.47 & $28.26 \mathrm{~b}$ & $29.45 \mathrm{ab}$ & $3.71 \mathrm{a}$ \\
\hline & & $\mathrm{Mn}$ & $2.57 \mathrm{ab}$ & 0.26 & $0.43 \mathrm{bc}$ & 0.10 & 0.13 & $26.64 \mathrm{a}$ & 10.51 & $24.51 \mathrm{~b}$ & $34.01 \mathrm{a}$ & $2.97 \mathrm{~b}$ \\
\hline & & $\mathrm{Zn}$ & $2.63 \mathrm{ab}$ & 0.25 & $0.48 \mathrm{ab}$ & 0.10 & 0.13 & $25.35 \mathrm{a}$ & 10.43 & $33.40 \mathrm{a}$ & $28.72 b$ & $3.62 \mathrm{a}$ \\
\hline & & Control & $2.33 \mathrm{c}$ & $0.27 \mathrm{~b}$ & $0.38 \mathrm{c}$ & $0.09 \mathrm{~b}$ & 0.17 & $26.36 \mathrm{ab}$ & $11.36 \mathrm{ab}$ & $20.66 \mathrm{c}$ & $28.88 \mathrm{bc}$ & 2.84 \\
\hline & \multirow{5}{*}{2018} & K & $2.83 \mathrm{ab}$ & $0.30 \mathrm{ab}$ & $0.56 \mathrm{a}$ & $0.12 \mathrm{a}$ & 0.18 & $32.28 \mathrm{a}$ & $12.51 \mathrm{ab}$ & $28.55 \mathrm{ab}$ & $32.97 \mathrm{~b}$ & 2.82 \\
\hline & & B & $2.60 \mathrm{bc}$ & $0.28 \mathrm{ab}$ & $0.50 \mathrm{~b}$ & $0.11 \mathrm{a}$ & 0.18 & $29.41 \mathrm{ab}$ & $13.03 \mathrm{a}$ & $29.87 \mathrm{ab}$ & $27.92 \mathrm{c}$ & 4.08 \\
\hline & & $\mathrm{N}$ & $3.05 \mathrm{a}$ & $0.29 \mathrm{ab}$ & $0.48 \mathrm{~b}$ & $0.09 \mathrm{~b}$ & 0.18 & $25.33 \mathrm{~b}$ & $11.13 \mathrm{ab}$ & $29.74 \mathrm{ab}$ & $32.01 \mathrm{bc}$ & 4.30 \\
\hline & & $\mathrm{Mn}$ & $2.76 \mathrm{ab}$ & $0.26 \mathrm{~b}$ & $0.50 \mathrm{~b}$ & $0.11 \mathrm{a}$ & 0.18 & $27.71 \mathrm{ab}$ & $10.43 b$ & $25.82 \mathrm{~b}$ & $38.55 \mathrm{a}$ & 3.14 \\
\hline & & $\mathrm{Zn}$ & $2.75 \mathrm{~b}$ & $0.31 \mathrm{a}$ & $0.48 \mathrm{~b}$ & $0.10 \mathrm{a}$ & 0.18 & $24.41 \mathrm{~b}$ & $11.38 \mathrm{ab}$ & $32.85 \mathrm{a}$ & $31.77 \mathrm{bc}$ & 3.96 \\
\hline \multirow{12}{*}{ Demirci } & \multirow{7}{*}{2017} & Control & $2.06 \mathrm{~d}$ & 0.31 & $0.37 \mathrm{~d}$ & $0.09 \mathrm{~b}$ & $0.14 \mathrm{c}$ & $28.78 \mathrm{a}$ & $7.59 \mathrm{a}$ & $33.12 \mathrm{ab}$ & $30.30 \mathrm{a}$ & $2.58 \mathrm{ab}$ \\
\hline & & $\mathrm{K}$ & $2.22 \mathrm{c}$ & 0.24 & $0.54 \mathrm{a}$ & $0.08 \mathrm{~b}$ & $0.14 \mathrm{c}$ & $23.86 \mathrm{~b}$ & $4.81 \mathrm{~b}$ & $32.39 \mathrm{ab}$ & $18.64 \mathrm{c}$ & $2.19 \mathrm{~b}$ \\
\hline & & B & $2.60 \mathrm{~b}$ & 0.27 & $0.51 \mathrm{ab}$ & $0.10 \mathrm{ab}$ & $0.16 \mathrm{abc}$ & $29.82 \mathrm{a}$ & $8.14 \mathrm{a}$ & $30.90 \mathrm{ab}$ & $26.53 \mathrm{~b}$ & $2.29 \mathrm{~b}$ \\
\hline & & $\mathrm{N}$ & $2.75 \mathrm{a}$ & 0.28 & $0.48 \mathrm{abc}$ & $0.08 \mathrm{~b}$ & $0.17 \mathrm{ab}$ & $30.12 \mathrm{a}$ & $6.51 \mathrm{ab}$ & $25.50 \mathrm{c}$ & $25.36 \mathrm{~b}$ & $2.53 \mathrm{ab}$ \\
\hline & & $\mathrm{Mn}$ & $2.84 \mathrm{a}$ & 0.29 & $0.44 \mathrm{~cd}$ & $0.10 \mathrm{ab}$ & $0.17 \mathrm{a}$ & $29.14 \mathrm{a}$ & $8.08 \mathrm{a}$ & $34.43 \mathrm{a}$ & $25.86 \mathrm{~b}$ & $2.41 \mathrm{ab}$ \\
\hline & & $\mathrm{Zn}$ & $2.14 \mathrm{~cd}$ & 0.31 & $0.44 \mathrm{bc}$ & $0.13 \mathrm{a}$ & $0.15 \mathrm{bc}$ & $28.04 \mathrm{a}$ & $6.37 \mathrm{ab}$ & $29.36 \mathrm{bc}$ & $22.97 \mathrm{~b}$ & $2.86 \mathrm{a}$ \\
\hline & & Control & $2.21 \mathrm{~d}$ & $0.28 \mathrm{~b}$ & $0.34 \mathrm{~d}$ & $0.08 \mathrm{c}$ & $0.19 \mathrm{ab}$ & $30.16 \mathrm{~d}$ & $7.65 \mathrm{~b}$ & $36.41 \mathrm{a}$ & $21.86 \mathrm{c}$ & $3.08 \mathrm{~b}$ \\
\hline & \multirow{5}{*}{2018} & K & $3.23 \mathrm{a}$ & $0.33 \mathrm{a}$ & $0.58 \mathrm{a}$ & $0.08 \mathrm{c}$ & $0.20 \mathrm{a}$ & $35.58 \mathrm{ab}$ & $9.83 \mathrm{a}$ & $34.91 \mathrm{ab}$ & $35.46 \mathrm{a}$ & $2.96 \mathrm{~b}$ \\
\hline & & B & $2.96 \mathrm{~b}$ & $0.30 \mathrm{ab}$ & $0.51 b c$ & $0.10 \mathrm{bc}$ & $0.18 \mathrm{ab}$ & $32.18 \mathrm{~cd}$ & $8.86 \mathrm{ab}$ & $34.63 \mathrm{ab}$ & $25.38 \mathrm{bc}$ & $4.53 \mathrm{a}$ \\
\hline & & $\mathrm{N}$ & $3.26 \mathrm{a}$ & $0.30 \mathrm{ab}$ & $0.50 \mathrm{bc}$ & $0.07 \mathrm{c}$ & $0.18 \mathrm{~b}$ & $36.86 \mathrm{a}$ & $9.78 \mathrm{a}$ & $30.29 \mathrm{~b}$ & $26.92 \mathrm{~b}$ & $3.20 \mathrm{~b}$ \\
\hline & & $\mathrm{Mn}$ & $3.23 \mathrm{a}$ & $0.33 \mathrm{a}$ & $0.53 \mathrm{ab}$ & $0.12 \mathrm{a}$ & $0.20 \mathrm{a}$ & $29.85 \mathrm{~d}$ & $8.53 \mathrm{ab}$ & $35.31 \mathrm{ab}$ & $26.09 \mathrm{~b}$ & $3.07 \mathrm{~b}$ \\
\hline & & $\mathrm{Zn}$ & $2.51 \mathrm{c}$ & $0.30 \mathrm{ab}$ & $0.46 \mathrm{c}$ & $0.11 \mathrm{ab}$ & $0.18 \mathrm{~b}$ & $33.28 \mathrm{bc}$ & $5.58 \mathrm{c}$ & $31.81 \mathrm{ab}$ & $23.92 \mathrm{bc}$ & $2.40 \mathrm{~b}$ \\
\hline
\end{tabular}

The differences in the means were determined by the Duncan test according to $\mathrm{P} \leq 0.05$

Table 6- Average values of the macro and micro nutrient content of kernel

\begin{tabular}{|c|c|c|c|c|c|c|c|c|c|c|c|}
\hline & & $N(\%)$ & $P(\%)$ & $K(\%)$ & $\mathrm{Ca}(\%)$ & $\begin{array}{l}M g \\
(\%)\end{array}$ & Fe (ppm) & $\begin{array}{l}\mathrm{Cu} \\
(\mathrm{ppm})\end{array}$ & $\begin{array}{l}\mathrm{Zn} \\
(p p m)\end{array}$ & $\begin{array}{l}\text { Mn } \\
(\text { ppm })\end{array}$ & $\begin{array}{l}B \\
(p p m)\end{array}$ \\
\hline \multirow{2}{*}{ Year } & 2017 & $2.51 \mathrm{~b}$ & $0.27 \mathrm{~b}$ & 0.466 & 0.06 & 0.11 & $26.60 \mathrm{~b}$ & $8.99 \mathrm{~b}$ & $28.54 \mathrm{~b}$ & $26.51 \mathrm{~b}$ & $2.67 \mathrm{~b}$ \\
\hline & 2018 & $2.81 \mathrm{a}$ & $0.29 \mathrm{a}$ & 0.489 & 0.06 & 0.12 & $30.28 \mathrm{a}$ & $10.01 \mathrm{a}$ & $30.90 \mathrm{a}$ & $29.31 \mathrm{a}$ & $3.36 \mathrm{a}$ \\
\hline \multirow{2}{*}{ Location } & Demirci & 2.67 & $0.29 \mathrm{a}$ & 0.479 & 0.05 & 0.11 & $30.64 \mathrm{a}$ & $7.64 \mathrm{~b}$ & $32.42 \mathrm{a}$ & $25.77 \mathrm{~b}$ & 2.84 \\
\hline & Saruhanlı & 2.65 & $0.27 \mathrm{~b}$ & 0.476 & 0.07 & 0.12 & $26.24 \mathrm{~b}$ & $11.35 \mathrm{a}$ & $27.03 \mathrm{~b}$ & $30.05 \mathrm{a}$ & 3.20 \\
\hline \multirow{6}{*}{ Application } & Control & $2.22 \mathrm{e}$ & 0.27 & $0.37 \mathrm{c}$ & $0.03 \mathrm{c}$ & 0.11 & $26.07 \mathrm{~b}$ & $9.47 \mathrm{~b}$ & $26.89 \mathrm{c}$ & $26.22 \mathrm{~d}$ & $2.71 \mathrm{c}$ \\
\hline & $\mathrm{K}$ & $2.76 \mathrm{~b}$ & 0.28 & $0.55 \mathrm{a}$ & $0.05 \mathrm{bc}$ & 0.11 & $29.14 \mathrm{a}$ & $9.66 \mathrm{ab}$ & $30.65 \mathrm{ac}$ & $29.28 \mathrm{~b}$ & $2.61 \mathrm{c}$ \\
\hline & B & $2.64 \mathrm{c}$ & 0.28 & $0.49 \mathrm{~b}$ & $0.07 \mathrm{ab}$ & 0.12 & $29.76 \mathrm{a}$ & $10.55 \mathrm{a}$ & $30.48 \mathrm{ac}$ & $25.57 \mathrm{~d}$ & $3.26 \mathrm{ab}$ \\
\hline & $\mathrm{N}$ & $2.96 \mathrm{a}$ & 0.29 & $0.48 \mathrm{~b}$ & $0.04 \mathrm{c}$ & 0.11 & $29.58 \mathrm{a}$ & $9.48 \mathrm{~b}$ & $28.45 \mathrm{bc}$ & $28.44 \mathrm{bc}$ & $3.43 \mathrm{a}$ \\
\hline & $\mathrm{Mn}$ & $2.85 \mathrm{~b}$ & 0.28 & $0.47 \mathrm{~b}$ & $0.10 \mathrm{a}$ & 0.13 & $28.33 \mathrm{a}$ & $9.39 \mathrm{~b}$ & $30.02 \mathrm{ac}$ & $31.13 \mathrm{a}$ & $2.90 \mathrm{bc}$ \\
\hline & $\mathrm{Zn}$ & $2.51 \mathrm{~d}$ & 0.29 & $0.46 \mathrm{~b}$ & $0.10 \mathrm{a}$ & 0.11 & $27.77 \mathrm{ab}$ & $8.44 \mathrm{c}$ & $31.86 \mathrm{a}$ & $26.84 \mathrm{~cd}$ & $3.21 \mathrm{ab}$ \\
\hline \multicolumn{2}{|c|}{ Year* Location } & $*$ & ns & ns & ns & ns & ns & ns & ns & ns & ns \\
\hline \multicolumn{2}{|c|}{ Location* Application } & $* *$ & ns & ns & ns & ns & ns & ns & $*$ & $*$ & $* *$ \\
\hline \multicolumn{2}{|c|}{ Year* Application } & $*$ & ns & ns & ns & ns & $* *$ & ns & ns & $*$ & $*$ \\
\hline \multicolumn{2}{|c|}{ Location* Year* Application } & $*$ & ns & ns & ns & ns & ns & ns & ns & $*$ & ns \\
\hline
\end{tabular}

*: Significant at $\mathrm{P}<0.05$, **: Significant at $\mathrm{P}<0.01$. ns: Non-significance.

\section{Discussion}

\subsection{Fruit properties and yield}

Foliar applications of macro and micro nutrients have a positive effect on fruit quality and yield. In this study, important effects of applications were determined on fruit weight. In this regard, statistically, the highest value was obtained from the B application 
for this feature. This was followed by the $\mathrm{Zn}$ leaf application, in general. It is also emphasized by different researchers that $\mathrm{Zn}$ treatments had a positive effect on nut weight in Pecan (Hounnou et al. 2019) and pistachio (Najizadeh \& Khoshgoftarmanes 2019) than the untreated trees. As a result of $\mathrm{Zn}$ and B foliar application, nut weight and kernel ratio amount increased compared to other application for Persian walnut trees (Keshavarz et al. 2011). In the same variety, the highest value was obtained with B application in terms of nut weight (Acarsoy Bilgin et al. 2018). Similar results were found in this current study. Additionally, among the different $\mathrm{Zn}$ forms, zinc sulfate is the lowest-cost $\mathrm{Zn}$ treatment. As a matter of fact, Hounnou et al. (2019) achieved positive results with the same application. Confirming this, the zinc sulfate treatment had a positive effect on nut and kernel weight in both years. In Hazelnut B + Zn applications increased nut size and kernel weight (Horuz et al. 2021). In almond, soil and foliar $\mathrm{N}$ applications did not significantly affect the nut and kernel weight (Morais et al. 2020). A somewhat similar finding was obtained in this current study.

The plant nutrient deficiency has been reported to cause problems such as the shrinkage ratio of the kernel that is important for this variety (Şen 1986). In this study, the shrinkage ratio was low with the K application in Saruhanl location and these values were determined to be $22.50 \%$ (first year) and $21.66 \%$ (second year). Besides, it was found that shrinkage ratio varied according to location and years. There are differences in the shrinkage ratio of the genotypes (Simsek 2010). In another study on the same walnut cultivar, shrinkage ratio was approximately half of the control with K application (Acarsoy Bilgin et al. 2021). In this context, it was concluded that $\mathrm{K}$ foliar application is important in terms of kernel quality.

One of the most important properties in commercial production is high efficiency. Keshavarz et al. (2011) reported that the foliar application of zinc dramatically increased both fruit set and yield of walnut. The yield increase was recorded with $\mathrm{Zn}$ foliar application in pistachio (Mohammadmehdi et al. 2019; Najizadeh \& Khoshgoftarmanes 2019). There was a positive effect of B applications on yield (Acarsoy Bilgin et al. 2018). Zinc application was less effective than B application in terms of fruit yield effect by Keshavarz et al. (2011). A similar result was achieved in this study. In the research by Morais et al. (2020) investigating the effects of combined soil and foliar nitrogen fertilization applications on almond trees, it was stated that $\mathrm{N}$ fertilization was not effective on yield. On the contrary, in the current study, an increase in yield was recorded with foliar $\mathrm{N}$ application compared to the control in both locations and years. The higher yield of cashew nut was obtained with the foliar application of boron $(0.25 \%)+$ zinc $(0.5 \%)$ in addition to the application of N P K (1: $0.5: 0.5)$ (Gavit et al. 2020). In Tombul Hazelnut variety, the highest yield was obtained with the B $+\mathrm{Zn}$ applications (Horuz et al. 2021). The aforementioned fertilizers had a positive effect on Chandler walnut in this study. The effects of genotype, environment and interaction on fruit quality characteristics are mentioned (Forde, 1975). It was stated that the quality characteristics of 5 hazelnut varieties varied according to the altitudes $(100,350$ and $800 \mathrm{~m})$ (Gülsoy et al. 2019). Koyuncu et al. (2002) reported that the walnut grown at high altitudes are small, but the color values give better results. In addition, it was stated that the genotype selected at $710 \mathrm{~m}$ altitude in the Northeastern Anatolia Region increased the kernel weight and yield when grown in the Yolova ecology at sea level (Orman 2018). In Uşak ecology, at an average altitude of $650 \mathrm{~m}, 800 \mathrm{~m}$, and $900 \mathrm{~m}$, in the 'Chandler' variety, nut weight increased depending on the altitude (Büyüksolak et al. 2020). On the contrary, it decreased in this study. In a different study conducted our, it was emphasized that 'Chandler' variety may be suitable for Saruhanlı ecology (Bilgin et al. 2018). In support of this, in the current study of 'Chandler' walnut variety, it was observed that the properties were superior in Saruhanlı location compared to Demirci location, which has a high altitude. This situation is thought to be a result of favorable climatic conditions.

Ramos (1998) reported that walnut yield and fruit quality characteristics changed according to ecological conditions. One of the causes of the shrinkage is high temperature damage (Forde, 1975). Due to the low summer temperatures in the Demirci location, the weight that has not been filled up completely has decreased. In support of this, it was observed that the shrinkage ratio increased in Saruhanlı location, which has high summer temperatures.

\subsection{Nutrient concentrations of kernel}

Walnuts are a good source of macro and micro nutrients, which are very beneficial for human health (Abdallah et al. 2015; Simsek, 2016). Nutrient contents of 'Chandler' variety were revealed in the Uşak region, which is at an altitude of about $900 \mathrm{~m}$ in the inner western Anatolia, by Yıldız \& Sümbül (2019a). According to the results of the analysis; N contents of kernels were found $3.11 \%$, P $352.63 \mathrm{mg} / 100 \mathrm{~g}, \mathrm{~K} 449.02 \mathrm{mg} / 100 \mathrm{~g}$, Ca $159.42 \mathrm{mg} / 100 \mathrm{~g}, \mathrm{Mg} 122.45 \mathrm{mg} / 100 \mathrm{~g}, \mathrm{Fe} 2.96 \mathrm{mg} / 100 \mathrm{~g}, \mathrm{Zn} 2.07$ $\mathrm{mg} / 100 \mathrm{~g}, \mathrm{Mn} 3.78 \mathrm{mg} / 100 \mathrm{~g}$ and $\mathrm{Cu} 1.61 \mathrm{mg} / 100 \mathrm{~g}$. On the other hand, there are many selection studies in our country. Mineral substance contents of selected genotypes were determined (Gülsoy et al. 2016; Simsek, 2016; Y1lmaz \& Akça, 2017; Yıldız \& Sümbül, 2019b; Acar \& Kazankaya, 2020). In some research; the variation of K, P, Mg, Ca, Fe, Zn, Mn and Cu were found at 170-548, 223- 380, 81-549, 37-453, 1.20-6.90, 1.10-3.80, 1.20-18.37 and 0.50-3.22 mg/100g, respectively (Cosmulescu et al. 2010; Özcan et al. 2010; Tapia et al. 2013). According to the literature mentioned, it was determined that N, P, Ca and Mn content were low; $\mathrm{K}$ and $\mathrm{Zn}$ content were high; $\mathrm{Mg}$ and Fe contents were similar in this study.

In this current study, the differences in mineral content of kernel were determined in year, location and foliar nutrient application. In addition, interactions were found to be effective in some applications. The positive effects of the applications occurred compared to the control of the nutrients of the kernel. On the other hand, with the $\mathrm{N}$ foliar application, the $\mathrm{N}$ content of kernel ranked the first row in both locations and years. A similar situation was observed in the K application. 
Mineral composition of kernel was varied significantly among accessions at 650-1996 m altitude in Morocco (Kabiri et al. 2019). In this study, the change depending on the locations was determined in the research conducted at different altitude. In general, mineral content was found higher in Demirci location. Differences have emerged in the studies conducted on nutrient content in walnut varieties and genotypes in our country and in the world. It is thought that there are different factors in the emergence of this condition such as genetic characteristics, climate conditions, soil type, agricultural practice and harvest dates (Caglarirmak 2003; Ozcan et al. 2010; Y1lmaz \& Akça 2017; Gülsoy et al. 2016; Batun et al. 2017).

No data were found on the effect of foliar nutrient applications on the kernel nutrient content of walnuts. On the other hand, applications of $\mathrm{K}_{2} \mathrm{SO}_{4}$ and $\mathrm{ZnSO}_{4}$ affected concentrations of $\mathrm{P}, \mathrm{K}, \mathrm{Mg}, \mathrm{Zn}, \mathrm{Mn}$ and $\mathrm{Fe}$ in the leaves of pistachio, but nutrient treatments had no effect on leaf concentration of $N$ (Norozi et al. 2019). In this study carried out in the Chandler variety, these applications had a positive effect on the kernel $\mathrm{N}$ content. In pecan trees treated with $\mathrm{Zn}$, manganese was low, but $\mathrm{Cu}$ and $\mathrm{Fe}$ contents were different. However, its effects have varied over the years (Hounnou et al. 2019). In this current study, however, the positive effect of $\mathrm{Zn}$ application was observed. Similar to the change in leaf nutrient content by years, the same change was observed in fruit content.

\section{Conclusions}

Plant nutrition applications are important in terms of growing. In this context, foliar application of B and $\mathrm{Zn}$ was observed in terms of nut weight. The shrinkage ratio, an important quality criterion for walnuts, was found to be low in the high altitude Demirci location. However, in the low altitude Saruhanli location, the shrinkage ratio was reduced with foliar $\mathrm{K}$ application. When the data were evaluated in general, walnut yield and fruit quality characteristics changed according to ecological conditions. Further, all foliar applications had positive effect on yield. The differences in mineral content of kernel were determined in year, location and application. But in general, mineral content was found higher in Demirci location. Thus, it was observed that the properties were superior in Saruhanl1 location compared to Demirci location, which has a high altitude.

\section{Acknowledgements}

Thanks to Ege University Scientific Research Projects Coordination Unit for the financial support provided to the conducting of this research.

\section{References}

Acar S \& Kazankaya A (2020). Some Fruit Properties and Macro-Micro Element Contents of Selected Walnuts (Juglans regia L.) from Batman Region. YYU Journal of Agricultural Science 30(2): 243-251. doi:10.29133/yyutbd.698507 (in Turkish).

Acarsoy Bilgin N, Yağız Y \& Misırlı A (2021). Effects of Some Nutrient Foliar Application on Yield and Quality in Walnut (cv. 'Chandler'). Agriculture Engineering. issue: 371: 51-58. doi:10.33724/zm.728414 (in Turkish).

Acarsoy Bilgin N, Şen F, Yağmur B, Özaktan H \& Akbaba M (2018). The First Findings to Fruit Characteristics of Nutrient and PGPR Applications on Chandler Walnut Variety. International Conference on Agriculture, Forest, Food, Veterinary Sciences and Technologies. Çeşme, İzmir. 769-775

Abdallah I B, Tlili N, Martinez-Force E, Rubio A G P, Perez-Camino M C, Albouchi A \& Boukhcina S (2015). Content of carotenoids, tocopherols, sterols, triterpenic and aliphatic alcohols, and volatile compounds in six walnuts (Juglans regia L.) varieties. Food Chem., 173: $972-978$

Aşkın M A \& Gün A (1995). Studies on breeding of Çameli and Bozkurt walnuts (Juglans regia L.) by selection. II. National Horticultural Congress in Turkey. pp. 461-463. 3-6 October Adana (in Turkish).

Batun P, Bakkalbaşı E, Kazankaya A \& Cavidoğlu İ (2017). Fatty Acid Profiles and Mineral Contents of Walnuts from Different Provinces of Van Lake. GIDA. 42(2): 155-162. doi: 10.15237/gida.GD16062

Beyhan Ö (1993). Research on Selectional Breeding of Darende Walnut (Juglans regia L.). Doctorate thesis. Yüzüncü Y1l University. Graduate School of Natural and Applied Sciences. Van. (in Turkish).

Bilgin S, Şen F, Özeker E \& Acarsoy Bilgin N (2018). Determination of Morphological and Pomological Characteristics of Some Walnut Cultivars in Menemen Conditions. COMU J. Agric. Fac 6(1): 31-39 (in Turkish).

Brown P (2001). Can boron correct transient nutrient deficiencies. Fluid Journal pp. 3

Büyüksolak Z N, Aşkın M A, Kahramanoğlu İ \& Okatan V (2020). Efects of Altitude on the Pomological Characteristics and Chemical Properties of 'Chandler' Walnuts: A Case Study in Uşak Province. Acta Agrobotanica. Volume 73, Issue 3, Article 7333. doi: 10.5586/aa.7333

Caglarirmak N (2003). Biochemical and physical properties of some walnut genotypes (Juglan regia L.) of the East Black Sea region of Turkey. Nahrung/Food 41(1): 28-32

Carranca C, Brunetto G \& Tagliavini M (2018). Nitrogen nutrition of fruit trees to reconcile productivity and environmental concerns. Plants. 7(1):4. doi:10.3390/plants7010004

Cosmulescu S, Botu M \& Trandafir I (2010). Mineral composition and physical characteristics of walnut (Juglans regia L.) cultivars originating in Romania. Selcuk Journal of Agriculture and Food Sciences 24(4): 33-37. (in Turkish).

Çolakoğlu H \& Çiçekli M (2016). Foliar Fertilization Guide. Toros Agriculture. (in Turkish).

Dejampour J \& Zeinalabedini M (2006). Determination of some vegetative and bloom characteristics of some local apricots in Azarbaijan (Iran) ecological conditions. Acta Hort 717: 63-65. doi: 10.17660/ActaHortic.2006.717.9 
Ellis Z (2016). Effect of Foliar Nutrient Combinations on Zinc Uptake in Almonds. A thesis submitted in partial fulfillment of the requirements for the degree of Master of Science in Plant Science in the Jordan of College of Agricultural Sciences and Technology California State University, Fresno.master's thesis (unpublished)

Epstein E \& Bloom AJ (2005). Mineral Nutrition of Plants: Principles and Perspectives, pp. 380

Fernandez V, Sotiropoulos T \& Brown P (2013). Foliar Fertilization: Scientific Principles and Field Practices. University of California Division of Agriculture and Natural Resources. International Fertilizer Industry Association (IFA). 144 pp. Paris, France.

Forde H I (1975). Walnuts. In: Editors Janickand J, Moore J N. Advances in Fruit Breeding pp. 439-455

Gavit S, Dodak SB \& Khobragade NH (2020). Application of different levels of NPK along with soil and foliar application of zinc and boron in cashew for increasing production with sustainability. IJCS 2020; 8(1): 3091-3094 doi:10.22271/chemi.2020.v8.i1au.8740

Ghani M A, Mushtaq A, Ziaf K, Ali B, Jahangir M M, Khan R W, Khan I, Azam M \& Noor A (2021). Exogenously Applied GA3 Promotes Plant Growth in Onion by Reducing Oxidative Stress Under Saline Conditions. Journal of Agricultural Sciences 27(2): 122-128. Doi: 10.15832/ankutbd.621546

Gülsoy E, Kaya T, Pehluvan M \& Şimşek M (2016). Some pomological properties and chemical contents of selected walnut (Juglans regia L.) genotypes from Iğdır province. Anadolu J Agr Sci 31: 309-314. doi: 10.7161/anajas.2016.31.3.309-314

Gülsoy E, Şimşek M \& Çevik C (2019). Determination of Fruit Quality Traits in Some Hazelnut Cultivars Grown at Different Altitudes and Locations in Ordu Province. (International Journal of Agriculture and Wildlife Science 5(1): 25-30. doi: 10.24180/ijaws.506932 (in Turkish).

Hounnou L, Brorsen B W, Biermacher J T \& Rohla C T (2019). Foliar applied zinc and the performance of pecan trees. Journal of Plant Nutrition, 42(5): 512-516. doi:10.1080/01904167.2019.1567771

Horuz A, Güneş A, Turan M, Demir T, Serdar Ü, Ozlu E, Karaman M R \& Fırıldak G (2021). The Effects of Different Micronutrient Fertilizers on cv. Tombul Hazelnut Yield and Certain Nut Properties. Erwerbs-Obstbau. 63:107-114. doi: 10.1007/s10341-021-00546-w

Juranovic Cindric I, Zeiner M \& Hlebec D (2018). Mineral Composition of Elements in Walnuts and Walnut Oils. Int. J. Environ. Res. Public Health, 15, 2674. doi:10.3390/ijerph15122674

Kabiri G, Bouda S, Elhansali M \& Haddioui A (2019). Biochemical characterization and antioxidant activity of walnut kernel (Juglans regia L.) of accessions from Middle and High Atlas in Morocco. Acta Scientiarum. Biological Sciences, v. 41, e46411. doi: 10.4025/actascibiolsci.v41i1.46411

Kacar B \& İnal A (2008). Plant Analysis, Nobel Publication, Ankara, No: 1241, 892 (in Turkish).

Kacar B \& Katkat AV (2006). Plant nutrition. Nobel Publication No: 849.593 s (in Turkish).

Kacar B (1982). Fertilizers and Fertilization Technique. 1982. Ankara, 341 s (in Turkish).

Keshavarz K, Vahdati K, Samar M, Azadegan B \& Brow PH (2011). Foliar Application of Zinc and Boron Improves Walnut Vegetative and Reproductive Growth. Hort Technology. 21(2):181-186. doi: 10.21273/HORTTECH.21.2.181

Khayyat M, Tafazoli E, Eshghi S \& Rajaee S (2007). Effect of nitrogen, boron, potassium and zinc sprays on yield and fruit quality of date palm. American Eurasian J. Agric \&Environ. Sci. 3: 289-296

Khoshgoftarmanesh A H (2012). Advanced plant nutrition concepts. Isfahan, Iran: Isfahan University of Technology Publication, 538 pp.

Kim T \& Wetzstein H Y (2005). Seasonal fluctuations in nutrients and carbohydrates in pecan leaves and stems. Journal of Horticultural Science \& Biotechnology 80(6):681-688. doi:10.1080/14620316.2005.11511998

Koyuncu F, Koyuncu M A, Erdal İ \& Yaviç A (2002). Chemical composition of fruits of some walnut (Juglans regia L.) selections. FOOD, 27(4): 247-251

Marchand M (2020). Efficiency of foliar applications of potassium sulphate on walnut production. XXX International Horticultural Congress IHC2018. doi: 10.17660/ActaHortic.2020.1280.15

Mohammadmehdi N, Valizadeh Kaji B, Karimi R \& Sedghi MN (2019). Effects of Foliar Application of Potassium and Zinc on Pistachio (Pistacia vera L.) Fruit Yield. International Journal of Horticultural Science and Technology 6(1): 113-123. doi: 10.22059/ijhst.2019.278757.286

Morais M C, Aires A, Barreales D, Rodrigues M A, Ribeiro A C, Gonçalves B \& Silva A P (2020). Combined Soil and Foliar Nitrogen Fertilization Effects on Rainfed Almond Tree Performance. Journal of Soil Science and Plant Nutrition 20: 2552-2565. doi: $10.1007 /$ s42729-020-00321-y

Najizadeh A \& Khoshgoftarmanes A H (2019). Effects of foliar applied zinc in the form of ZnSO4 and Zn-amino acid complexes on pistachio nut yield and quality. Journal of Plant Nutrition 42(18): 2299-2309. doi: 10.1080/01904167.2019.1655043

Norozi M, ValizadehKaji B, Karimi R \& Nikoogoftar Sedghi M (2019). Effects of Foliar Application of Potassium and Zinc on Pistachio (Pistacia vera L.) Fruit Yield. International Journal of Horticultural Science and Technology 6(1): 113-123. doi: 10.22059/ijhst.2019.278757.286

Orman E (2018). Agro-Morphological and Molecular Identification of Some Local Walnut (Juglans regia L.) Genotypes. (PhD. In Horticulture). Ege University Graduate School of Natural and Applied Sciences Bornova/İzmir (in Turkish).

Ozcan MM, Iman C \& Arslan D (2010). Physico-chemical properties, fatty acid and mineral content of some walnuts (Juglans regia L.) types. Agricultural Sciences 1: 62-67. doi:10.4236/as.2010.12009

Ozyigit İ İ, Uras M E, Yalcin İ E, Severoglu Z, Demir G, Borkoev B, Salieva K, Yucel S, Erturk Ü \& Solak A O (2019). Heavy Metal Levels and Mineral Nutrient Status of Natural Walnut (Juglans regia L.) Populations in Kyrgyzstan: Nutritional Values of Kernels. Biological Trace Element Research. 189:277-290. doi: 10.1007/s12011-018-1461-4

Özçağıran R, Ünal A, Özeker E \& İsfendiyaroğlu M (2014). Temperate Climate Fruit Species, Nuts Volume III, Ege University Faculty of Agriculture Publications No: 566 (in Turkish).

Ramos DE (1998). Walnut Production Manual. University of California. Division of Agriculture and Natural Resources. Publication, 3373. $319 \mathrm{pp}$.

Rios J J, Yepes-Molina L, Martinez-Alonso A \& Carvajal M (2020). Nanobiofertilization as a novel technology for highly efficient foliar application of Fe and B in almond trees. R. Soc. Open Sci. 7: 200905. doi: 10.1098/rsos.200905

Rios J J, Garcia-Ibanez P \& Carvajal M (2019). The use of biovesicles to improve the efficiency of Zn foliar fertilization. Colloids and Surfaces B: Biointerfaces. Volume 173, Pages 899-905. doi: 10.1016/j.colsurfb.2018.10.057

Scherz H \& Kirchhoff E (2006). Trace elements in foods: Zinc contents of raw foods-A comparison of data originating from different geographical regions of the world. J. Food Compos. Anal 19: 420-433 
Simsek M (2010). Selection of walnut types with high fruit bearing and quality in Sanliurfa population. International Journal of the Physical Sciences Vol. 5(7), pp. 992-996

Simsek M (2016). Chemical, mineral, and fatty acid compositions of various types of walnut (Juglans regia L.) in Turkey. Bulgarian Chemical Communications. 48(1): 66-70

Smith C A, Walworth J L, Richard M J, Joshua J \& Sherman D (2021). Does Foliar Zinc Application Boost Leaf Photosynthesis of 'Wichita' Pecan Fertigated with Zinc-EDTA? HORTSCIENCE 56(5): 579-582. doi:10.21273/HORTSCI15692-21

Şen S M (1980). Studies on the Breeding of Walnuts (Juglans regia L.) in North East Anatolia and the Eastern Black Sea Region by Selection. Associate Professor Thesis, (unpublished) Ataturk University. Erzurum (in Turkish).

Şen S M (1986). Walnut Cultivation. Eser Printing House, Samsun (in Turkish).

Tapia M I, Sanchez-Margado J R, Garcia-Parra J, Ramirez R, Hernandez T \& Gonzales-Games D (2013). Comparative study of the nutritional and bioactive compounds content of four walnut (Juglans regia L.) cultivars. Journal of Food Composition and Analysis 31: 232-237. doi: 10.1016/j.jfca.2013.06.004

Wolf B (1971). The determination of boron in soil ekstracts, plant material components, manures, waters and nutrient solutions, Soil Sci. Plant Anal 2(5): 363-374. doi: 10.1080/00103627109366326

Xie R, Zhao J, Lu L, Brown P H, Guo J \& Tian S (2020). Penetration of foliar-applied Zn and its impact on apple plant nutrition status: in vivo evaluation by synchrotron-based X-ray fluorescence microscopy. Horticulture Research 7: 147. doi: 10.1038/s41438-020-00369-y

Xu C, Guo S \& Wang J (2021). Exogenous nitrogen uptake and allocation in chestnut. Can. J. Plant Sci. 101: 307-314. doi: 10.1139/cjps2019-0326

Yıldız A, Yıldız A, Doran İ, Aydın A \& Keleş D (2007). The effects of inorganic and organic fertilizers on the growth, yield and fruit quality of apricot species Precoce de Tyrinthe. Alatarım 6(2): 1-8p (in Turkish).

Yılmaz S \& Akça Y (2017). Determination of biochemical properties and fatty acid composition of new walnut (Juglans regia) genotypes. J. Agric. Fac. Gaziosmanpasa Univ. 34 (2): 74-80

Y1ldız E \& Sümbül A (2019a). Mineral content in kernel of some local and foreign walnut cultivars and genotypes. Mustafa Kemal University Journal of Agricultural Sciences 24 (3):174-180

Yıldız E \& Sümbül A (2019b). Determination of Mineral Content in Kernel of Walnut Genotypes Selected from Uşak/Turkey. Adnan Menderes University Journal of the Faculty of Agriculture 16(2):179-183 doi: 10.25308/aduziraat.562837 (in Turkish).

(C) 2022 by the author(s). Published by Ankara University, Faculty of Agriculture, Ankara, Turkey. This is an Open Access article distributed under the terms and conditions of the Creative Commons Attribution (CC BY) license (http://creativecommons.org/licenses/by/4.0/), which permits unrestricted use, distribution, and reproduction in any medium, provided the original work is properly cited. 